Alvim et al., Revista Brasileira de Higiene e Sanidade Animal (v.13, n.1) p. 98 - 105 jan - mar (2019)

Revista Brasileira de Higiene e Sanidade Animal

Brazilian Journal of Hygiene and Animal Sanity

ISSN: 1981-2965

\title{
Basophilic stippling and reactive lymphocytosis in bovine anaplasmosis - A case
} report

Pontilhado Basofílico e Linfocitose Reativa na anaplasmose bovina - Relato de caso

\section{Gabriela Rotatori Alvim ${ }^{1}$, Lara Garcia Costa ${ }^{2}$, Maurício Deschk ${ }^{3}$, Adolfo Firmino Silva-Neto ${ }^{4}$, Rafael Ferreira de Araujo ${ }^{5}$, Carina Franciscato ${ }^{6} *$}

\begin{abstract}
Anaplasmosis is known for causing anemia in cattle. However, morphological changes in the red and white blood cells are not often described in bovine anaplasmosis cases. Thus, the aim of this work was to describe changes in blood cell morphology, such as the incidence of basophilic stippling in red blood cells and the reactive lymphocytosis, presented by a 10-month-old Jersey heifer, who was bred in a dairy farm in Juiz de Fora County (MG), Forest Zone of Minas Gerais State (Zona da Mata Mineira). The animal presented clinical signs of hyperthermia and hypocorous mucosae, which suggested hemoparasitosis. Laboratory examination demonstrated the presence of Anaplasma marginale in several erythrocytes, $13.4 \%$ of parasitemia, red blood cells presenting basophilic stippling, severe macrocytic normochromic anemia, increased total number of leukocytes resulting from the increased number of lymphocytes, some large lymphocytes with basophilic cytoplasm, and other lymphocytes showed granules in the cytoplasm. These findings are not often described in bovine anaplasmosis cases. So, this work shows the relevance of blood smear examinations to diagnose the hemoparasite, as well as to identify cellular morphological changes caused by it.
\end{abstract}

Keywords: Anaplasmosis, basophilic stippling, hemogram, reactive lymphocyte, anemia.

Resumo: A anaplasmose é conhecida por causar anemia em bovinos. Entretanto, alterações morfológicas nas células vermelhas e brancas não são frequentemente descritas em casos de anaplasmose bovina. Assim, o objetivo deste trabalho foi mostrar alterações na morfologia de células sanguíneas pouco descritas em bovinos com anaplasmose, como a presença de pontilhado basofílico em hemácias e a linfocitose reativa, apresentadas por uma bezerra, de 10 meses, da raça Jersey pertencente a uma fazenda de gado de leite na cidade de Juiz de Fora - MG, região da Zona da Mata Mineira. O animal apresentou sinais clínicos sugestivos de hemoparasitose, como mucosas hipocoradas. Os exames laboratoriais demonstraram a presença de Anaplasma marginale em várias hemácias, $13.4 \%$ de parasitemia, hemácias apresentando pontilhado basofílico, severa anemia macrocítica normocrômica, aumento do número de leucócitos totais resultante do aumento de linfócitos, alguns linfócitos grandes com citoplasma basofílico, e outros linfócitos com grânulos no citoplasma. Estes achados não são comumente descritos na anaplasmose bovina. Portanto, este trabalho mostrou a relevância do exame do esfregaço sanguíneo para diagnóstico do hemoparasito, bem como para identificação das variações morfológicas celulares que este pode causar.

Palavras-chave: Anaplasmose, pontilhado basofílico, hemograma, linfócitos reativos, anemia.

\footnotetext{
*Autor Correspondente - E-mail: carinafranciscato@yahoo.com.br

Recebido em 10.11.2018. Aceito em 30.03.2019

http://dx.doi.org/10.5935/1981-2965.20190007

${ }^{1}$ Universidade Federal de Juiz de Fora (UFJF). E-mail: gabirotatori@ @otmail.com

${ }^{2}$ Universidade Federal de Juiz de Fora (UFJF). E-mail: laragarciac21@ hotmail.com

${ }^{3}$ Universidade Federal de Juiz de Fora (UFJF). E-mail: mauricio.deschk@ufjf.edu.br
} 
Alvim et al., Revista Brasileira de Higiene e Sanidade Animal (v.13, n.1) p. 98 - 105 jan - mar (2019)

${ }^{4}$ Docente - Universidade Federal de Juiz de Fora (UFJF). E-mail: adolfo.neto@ufjf.edu.br

${ }^{5}$ Docente - Universidade Federal de Juiz de Fora (UFJF) E-mail: rafael.araujo@ufjf.edu.br

${ }^{6}$ Docente - Universidade Federal de Juiz de Fora (UFJF).

\section{Introduction}

Bovine anaplasmosis is an infection caused by bacteria such as Anaplasma marginale and Anaplasma centrale, which belong to Family Anaplasmataceae (Teruel et al., 2009) - A. marginale is the most pathogenic and significant species affecting cattle (PALMER, 1989). This rickettsia can be biologically transmitted through hematophagous insects or contaminated fomites (Trindade et al., 2011), besides being experimentally demonstrated in more than 20 tick species belonging to Family Ixodidae (KOCAN et al., 2005). However, the relevance of each of these species in the transmission of the aforementioned disease under natural conditions remains poorly defined (Gonçalves-Ruiz et al., 2002). The tick species Rhipicephalus (Boophilus) microplus is endemic to Brazil; therefore, epidemiological evidences suggest that this species is the main vector for A. marginale (GUGLIELMONE，1995; KESSLER \& SCHENK, 1998).

A. marginale is an obligate intraerythrocytic rickettsial gram-negative bacterium that causes extravascular hemolytic anemia and whose physiopathogenic mechanism can be immunomediated through antibody formation against microorganisms to enable phagocytosis by macrophages (RIBEIRO et al., 1995). Lymphocytes must be antigenically stimulated in order to form antibodies (Abbas et al., 2015). Therefore, besides the increased number of macrophages (Bernardo et al., 2016a), proliferative lymphocytosis is one of the changes found in white cells of animals infected with Anaplasma sp. (ALSAAD, 2009).

Hemolytic anemia is often classified as a regenerative disease characterized by anisocytosis and polychromasia, which are representative of reticulocytes (THRALL et al., 2007). However, it is known that reticulocyte count in cattle is not representative of regeneration, since ruminants often present slight red blood cell release from the bone marrow. On the other hand, the incidence of basophilic stippling in red blood cells during intense body response to anemia is a species-specific feature of ruminants affected by regenerative anemia (JAIN, 1993).

The aim of the current study was to investigate changes in blood cell morphology, such as the incidence of 
Alvim et al., Revista Brasileira de Higiene e Sanidade Animal (v.13, n.1) p. 98 - 105 jan - mar (2019)

basophilic stippling in red blood cells and the reactive lymphocytosis, which are poorly described in anaplasmotic bovines.

\section{Case Report}

The study reports the case of a 10month-old Jersey heifer, who was bred in a dairy farm in Juiz de Fora County (MG), Forest Zone of Minas Gerais State (Zona da Mata Mineira). The animal presented clinical signs of hypocorous mucosae, which suggested hemoparasitosis. Blood samples were collected through venous puncture and sent to the Veterinary Clinical Pathology Laboratory of Federal University of Juiz de Fora (UFJF Universidade Federal de Juiz de Fora) for complete blood count and hemoparasite screening.

Parasitemia estimates were based on direct agent examination in the animal's blood. Blood smears were stained with Diff-Quick. After the staining procedure was over, smear microscopy was applied to 100 microscopic fields using immersion objective lens (1000x magnification), as recommended by ALMOSNY (2002). The number of parasitized erythrocytes was estimated by taking into consideration the count of 1000 red blood cells in the blood smear - results were expressed in percentage $(\%)$, based on VIEIRA et al. (2001).

The microscopic examination of the blood smear stained with Diff-Quick found intense anisocytosis (Figure 1A), red blood cells presenting basophilic stippling (Figure 1B) and several erythrocytes presenting Anaplasma marginalecompatible inclusions (Figure 2).

The animal recorded $13.4 \%$ parasitemia. In addition, it presented some large lymphocytes (Figure 3A) with basophilic cytoplasm (Figure 3B), whereas other lymphocytes showed granules in the cytoplasm (Figure 3C).

Erythrogram results (Table 1) evidenced decreased number of red blood cells, as well as low hemoglobin and hematocrit values consistent with severe macrocytic normochromic anemia.

Leukogram results (Table 1) recorded increased total number of leukocytes resulting from the increased number of lymphocytes. 
Alvim et al., Revista Brasileira de Higiene e Sanidade Animal (v.13, n.1) p. 98 - 105 jan - mar (2019)

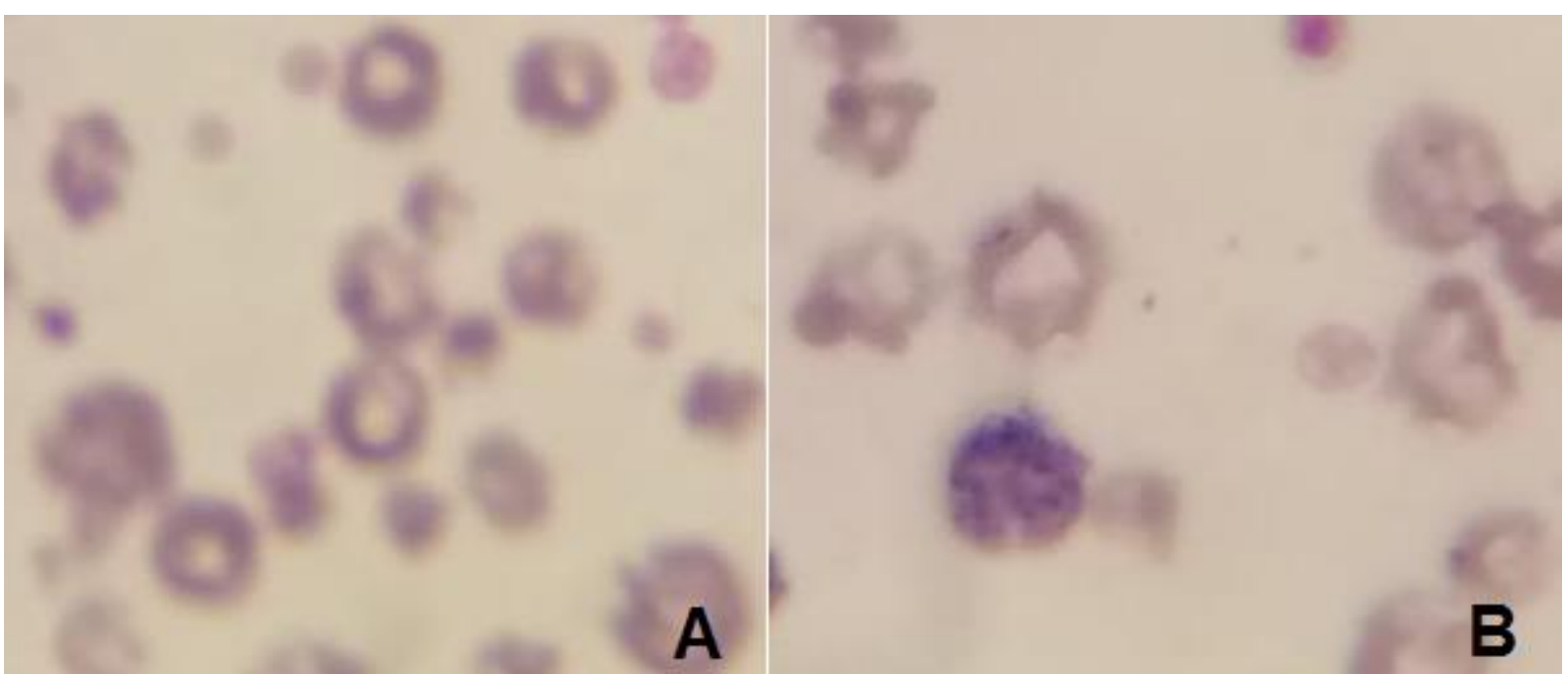

Figure 1. Intense anisocytosis (A); red blood cell presenting basophilic stippling (B).

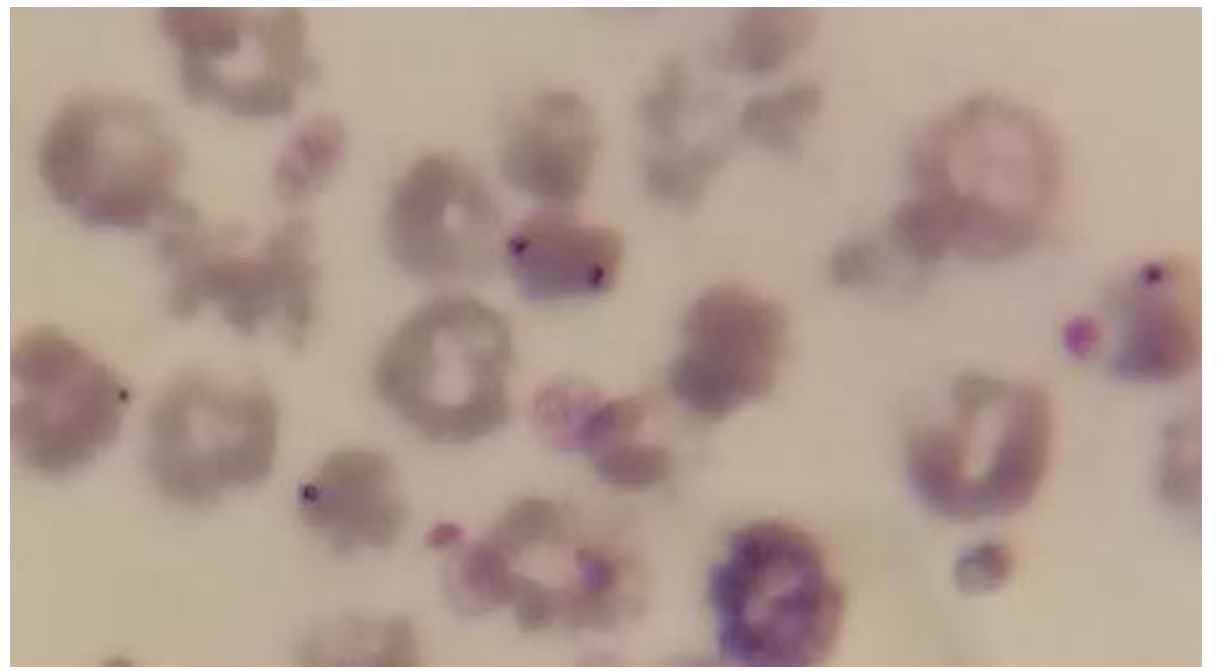

Figure 2. Blood smear showing intraerythrocytic bodies befitting with Anaplasma marginale.



Figure 3. Large lymphocyte (A); Lymphocyte with basophilic cytoplasm (B); Lymphocytes with granules in the cytoplasm (C). 
Alvim et al., Revista Brasileira de Higiene e Sanidade Animal (v.13, n.1) p. 98 - 105 jan - mar (2019)

Tabela 1 - Hematological and biochemical parameters of heifer infected naturally by Anaplasma marginale.

\begin{tabular}{ccc}
\hline Parameters & Results & Reference Values \\
\hline Erythrocytes & 1,68 & $5-10(\mathrm{x} 106 / \mu \mathrm{l})^{\mathrm{a}}$ \\
Hemoglobin & 3,3 & $8-15(\mathrm{~g} / \mathrm{dl})^{\mathrm{a}}$ \\
Hematocrit & 10,8 & $24-46(\%)^{\mathrm{a}}$ \\
MCV 1 & 64,1 & $40-60(\mathrm{fL})^{\mathrm{a}}$ \\
MCHC & 30,7 & $30-36(\%)^{\mathrm{a}}$ \\
Total Leukocytes & 13500 & $4.000-12.000 / \mu \mathrm{L}^{\mathrm{a}}$ \\
Lynphocytes & 10260 & $2.500-7.500 / \mu \mathrm{L}^{\mathrm{a}}$ \\
Neutrophils & 3240 & $600-4.000 / \mu \mathrm{L}^{\mathrm{a}}$ \\
Monocytes & 0 & $25-840 / \mu \mathrm{L}^{\mathrm{a}}$ \\
Eosinophils & 0 & $0-2.400 / \mu \mathrm{L}^{\mathrm{a}}$ \\
\hline
\end{tabular}

${ }^{1}$ Mean Corpuscular Volume.

${ }^{2}$ Mean Corpuscular Hemoglobin Concentration.

${ }^{\mathrm{a}}$ Meyer e Harvey (1998)

\section{Discussion}

Anaplasmosis is known for causing anemia in cattle (GONÇALVES et al., 2005). However, results of the hemogram conducted in the blood smear of the herein reported case revealed morphological changes in the red and white blood cells of the analyzed animal - these changes are not often described in bovine anaplasmosis cases.

This animal presented severe anemia (10.8\% hematocrit) and many parasitized red blood cells (13.4\%). This result corroborates the study by Bernardo et al. (2016b), who reported that cattle infected with $A$. marginale presented clinical signs of the disease, even before recording $15 \%$ parasitemia.

Anemia in this animal was classified as macrocytic normochromic. This outcome corroborates the study by Yasini et al. (2012), who found this same anemia type in sheep experimentally infected with Anaplasma ovis. According to them, these sheep presented normocytic normochromic anemia; however, as the disease progressed, the animals presented increased MCV (Mean Corpuscular Volume) and evolved to macrocytic normochromic anemia. Thus, it is possible assuming that a similar process may have happened in the herein reported case, since 
Alvim et al., Revista Brasileira de Higiene e Sanidade Animal (v.13, n.1) p. 98 - 105 jan - mar (2019)

the heifer also presented increased MCV, which was consistent with the anisocytosis found in the blood smear. Anisocytosis associated with increased MCV indicates the incidence of larger red blood cells, which, in this case, represented young cells and indicated regeneration.

In addition, the heifer presented red blood cells with basophilic stippling (thinto-gross, blue-to-dark purple granules representing aggregate ribosomes dispersed through the cytoplasm of erythrocytes), which clinically mean regenerative anemia, mainly in cattle (Stockham \& Scott, 2011). These very changes were experimentally demonstrated in sheep infected with Anaplasma ovis (YASINI et al., 2012). However, studies describing this condition in cattle remain scarce in the literature.

The leukocytosis resulting from lymphocytosis presented by the heifer in our study was also described in young cattle (Bernardo et al., 2016a) and camels (Alsaad, 2009) naturally infected with $A$. marginale, as well as in small ruminants parasitized by Babesia sp (ESMAEILNEJAD et al., 2012; SULAIMAN et al., 2010). Mahran (2004) conducted a study with camel blood parasites and showed that lymphocytosis takes place during antibody formation in response to parasite antigen.

Besides lymphocytosis, the herein reported heifer presented morphological changes such as large lymphocytes with cytoplasmic basophilia. These basophilia characterized reactive lymphocytes (Reagan et al., 2011), which are antigenically-stimulated cells (HARVEY, 2001). The incidence of granules in the cytoplasm of some of these cells was another morphological change found in lymphocytes. Granular lymphocytes were described in inflammatory disorders (HARVEY, 2012). Ghazvinian \& Khodaiean (2016) reported similar lymphocytic changes in camels naturally infected with Anaplasma sp.

\section{Conclusion}

Although anaplasmosis is a common disease affecting bovine herds, hematological changes found in parasitized animals remain poorly reported. Thus, the current study described changes in cell morphology, such as basophilic stippling in red blood cells and reactive lymphocytes, which are essential to help better understanding the pathogenic mechanism of anaplasmosis in cattle. The relevance of blood smear examinations to diagnose the hemoparasite, as well as to identify cellular morphological changes caused by it, was also herein highlighted. 


\section{References}

1. ABBAS, A.K.; LICHTMAN, A.H.; PILLAI, S. Imunologia Celular e Molecular. 8. ed. Rio de Janeiro: Elsevier, 2015, 531p.

2. ALMOSNY, N.R.P. Hemoparasitoses em Pequenos Animais Domésticos e como Zoonoses. 1. ed. Rio de Janeiro: L. F.Livros, 2002. 135p.

3. ALSAAD, K.M. Clinical, Hematological and Biochemical Studies of Anaplasmosis in Arabian One-Humped Camels (Camelus dromedaries). Journal of Animal and Veterinary Advance, v.8, n.11, p.21062109, 2009.

4. BERNARDO, F.D.; FREITAS, F.L.C.; SILVA-NETO, A.F.; FRANCISCATO, C. Importance of blood smear in the distinction of hemoparasites: A case report of anaplasmosis. Revista Brasileira de Higiene e Sanidade Animal, v.10, n.2, p.290- 296, 2016 a.

5. BERNARDO, F.D.; CONHIZAK, C.; AMBROSINI, F.; SILVA-NETO, A.F.; FREITAS, F.L.C.; FRANCISCATO, C. Alterações hematológicas e bioquímicas causadas por Anaplasma marginale em bovinos com aptidão leiteira da região Sudoeste do Paraná. Revista Brasileira de Ciência Veterinária, v.23, n.3-4, p.152-156, 2016b.

6. ESMAEILNEJAD, B.; TAVASSOLI, M.; ASRI-REZAEI, S. Investigation of hematological and biochemical parameters in small ruminants naturally infected with Babesia ovis. Veterinary Research Fórum, v.3, n.1, p.31-36, 2012.

7. GHAZVINIAN, K.; KHODAIEAN, T. Anaplasmosis among Camels in Iran and Observation of Abnormalities in Infected Blood Films. International Journal of Animal and Veterinary Sciences, v.10, n.7, p.474-478, 2016.

8. GONÇALVES, R.C.; SILVA, D.P.G.; CHIACCHIO, S.B.; BORGES, A.S.; AMORIM, R.M.; BANDARRA, E.P.; TAKAHIRA, R.K. Anaplasmose Neonatal em bezerro. Veterinária Notícias, v.11, n.1, p.9598, 2005.

9. GONÇAVES-RUIZ, P.M.; PASSOS, L.M.; MARTINS, M.S.; PATARROYO, J.H.; RIBEIRO, M.F. Antigenic characterization of morphologically distinct Anaplasma marginale isolates using a panel of monoclonal antibodies. Veterinary Parasitology, v.29, n.107, p.169-177, 2002.

10. GUGLIELMONE, A. Epidemiologia y prevencion de los Hemoparasitos (Babesia y Anaplasma) en la Argentina. In: NARI, A., FIEL, C. Enfermidades parasitarias de importância econômica en bovinos. Montevideo, Uruguay: Hemisferio Sur, 1994. cap.23, p.460-479.

11. HARVEY, J.W. Atlas of veterinary hematology: blood and bone marrow of domestic animals. USA: W.B.Saunders Company, PA, 2001. 228p.

12. HARVEY, J.W. Veterinary Hematology. A Diagnostic guide and color atlas. St. Louis, Missouri, USA: Elsevier Sunders, 2012. 368p.

13. JAIN, N.C. Essentials ofveterinary hematology. 1ed. Philadelphia: Lea \& Febiger, 1993. 417p.

14. KESSLER, R.H.; SCHENK, M.A.M. Diagnóstico parasitológico da tristeza parasitária bovina. In: KESSLER, R.H.; SCHENK M.A.M. (ed.) Carrapato, Tristeza Parasitária e Tripanossomose dos Bovinos. Embrapa Gado de Corte, Campo Grande, MS. 1998. p.81- 90.

15. KOCAN, K.M.; YOSHIOKA, J.; SONENSHINE, D.E.; DE LA FUENTE, J.; CERAUL, S.M.; BLOUIN, E.F.; ALMAZÁN, C. Capillary tube feeding system for studying tick-pathogen interactions of Dermacentor variabilis (Acari: Ixodidae) and Anaplasma marginale (Rickettsiales: Anaplasmataceae). Journal of Medical Entomology, v.42, n.5, p.864-874, 2005.

16. MAHRAN, O.M. Some studies on blood parasites in camels (Camelus dromedarius) at Shalatin City, Red Sea Governorate. Assiut 
Veterinary Medical Journal, v.50, n.102, p.172-184, 2004.

17. MEYER, D.J.; HARVEY, J.W. Veterinary Laboratory Medicine: Interpretation and Diagnosis. Philadelphia: W.B. Saunders, 1998. 372 p.

18. PALMER, G.H. Anaplasma vaccines. In: WRIGHT, I. G. Veterinary protozoan and hemoparasite vacines. Boca Raton, Flórida: CR, 1989. cap.1, p.1-29.

19. REAGAN, W.S.; ROVIRA, A.I.; DENICOLA, D. Atlas de hematologia veterinária espécies domésticas e não domesticas comuns. 2. ed. Rio de Janeiro: Livraria e Editora REVINTER Ltda, 2011. 108p.

20. RIBEIRO, M.F.B.; LIMA, J.D.; GUIMARÃES, A.M.; MARTINS, N.E. Transmissão congênita da anaplasmose bovina. Arquivo Brasileiro de Medicina Veterinária e Zootecnia, v.47, n.3, p.297-304, 1995.

21. STOCKHAM, S.L.; SCOTT, M.A. Fundamentos de Patologia Clínica Veterinária. 2. ed. Rio de Janeiro: Guanabara Kooogan, 2011, 729p.

22. SULAIMAN, E.G.; ARSLAN, S.H.; ALOBAIDI, Q.T.; DAHAM, E. Clinical, haematological and biochemical studies of babesiosis in native goats in Mosul. Iraq Journal of Veterinary Sciences, v.24, n.1, p.31-35, 2010.

23. TERUEL, G.M.; SANTOS, M.S.P.; GOMES, I.T.; ASTRAUSKAS, J.P.; NAGASHIMA, J.C.; SACCO, S.R.; AVANZA, M.F.B.; BATISTA, J.C. Anaplasmose bovina - Relato de caso. Revista científica eletrônica de medicina veterinária - issn: 1679-7353, Garça, n.13, jul. 2009.

24. THRALL, M.A.; BAKER, D.C.; CAMPBELL, T.W. Hematologia e bioquímica clínica veterinária. São Paulo: Roca Ltda, 2007. 592 p.

25. TRINDADE, H.I; ALMEIDA, K.S; FREITAS, F.L.C. Tristeza parasitária bovina revisão de literatura. Revista científica eletrônica de Medicina Veterinária, Garça, n.16, jan. 2011.

26. VIEIRA, D.; MENDONÇA, C.L.; KOHAYAGAWA, A.; MADRUGA, C.R.; SCHENKI, M. A.; KESSLER, R. Avaliações da parasitemia, do hematócrito e dos níveis bioquímicos séricos, de bezerros nelore (Bos indicus), inoculados com isolados de Babesia bigemina (Smith \& Kilborne, 1893) das regiões sul, sudeste, centro-oeste, nordeste e norte do Brasil. Ciência Animal Brasileira, v.2, n.2, p.101-109, 2001.

27. YASINI, S.P.; KHAKI, Z.; RAHBARI, S.; KAZEMI, B.; SALAR-AMOLI, J.; GHARABAGHI, A.; JALALI, S.M. Hematologic and Clinical Aspects of Experimental Ovine Anaplasmosis Caused by Anaplasma ovis in Iran. Iranian Journal of Parasitology, v.7, n.4, p.91-98, 2012. 